\title{
AGGRESSIVE VERTEBRAL HEMANGIOMAS - CASE SERIES AND LITERATURE REVIEW
}

\author{
HEMANGIOMAS VERTEBRAIS DE COMPORTAMENTO AGRESSIVO - SÉRIE DE CASOS E \\ REVISÃO DA LITERATURA
}

\section{HEMANGIOMAS VERTEBRALES DE COMPORTAMIENTO AGRESIVO - SERIE DE CASOS Y REVISION DE LA LITERATURA}

\author{
lucas Xavier da Luz, ${ }^{1}$ Marcelo Simoni Simões, ${ }^{1}$ Bruno de Azevedo Oliveira, ${ }^{1}$ Gullherme José Miotto, ${ }^{1}$ Ernani Vianna de Abreu ${ }^{1}$ \\ 1. Hospital Ernesto Dornelles, Spine Group, Porto Alegre, RS, Brazil.
}

\begin{abstract}
Objectives: To present a series of aggressive hemangiomas of the institution, with a review of the management options described in the literature. Methods: This is a retrospective survey of aggressive vertebral hemangiomas treated by the service in the last 10 years, with histological confirmation of the diagnosis and a minimum follow-up of 1 year. The case analysis and literature review were conducted with emphasis on treatment options for these injuries. Results: Seven cases were found, three with pain and four with severe neurological deficits. Two patients were treated with open decompression, one with open decompression and cementation, one with open decompression and arthrodesis, one with biopsy and cementation, one with percutaneous biopsy, and one with open biopsy followed by decompression surgery. All patients underwent radiotherapy. There was a significant regression of presentation deficits, but one patient developed an irreversible deficit during treatment. There were no recurrences or late complications in the follow-up period. Conclusions: Surgical decompression in patients with significant neurological deficit is a point of consensus in the literature. Subtotal resection followed by radiation therapy was effective in treating deficits and controlling pathology. Cases manifesting pain only can be managed with minimally invasive techniques, whether or not they are followed by radiotherapy. Level of evidence IV; Therapeutic study of case series.
\end{abstract}

Keywords: Hemangioma; Neoplasms; Spine.

\section{RESUMO}

Objetivo: Apresentar a série de hemangiomas agressivos da instituição, com uma revisão das opções de manejo descritas na literatura. Métodos: Trata-se de um levantamento retrospectivo dos hemangiomas vertebrais agressivos atendidos pelo serviço nos últimos 10 anos, com confirmação histológica do diagnóstico e seguimento mínimo de um ano. Foi feita análise dos casos e revisão da literatura, com ênfase nas opções de tratamento dessas lesões. Resultados: Foram encontrados sete casos, três com dor e quatro com déficits neurológicos graves. Dois pacientes foram tratados com descompressão aberta, um com descompressão aberta e cimentação, um com descompressão aberta e artrodese, um com biópsia e cimentação, um com biópsia percutânea e um com biópsia aberta seguida de cirurgia descompressiva. Todos os pacientes foram submetidos à radioterapia. Houve regressão significativa dos déficits da apresentação, mas uma paciente desenvolveu déficit irreversível durante o tratamento. Não houve recidivas ou complicações tardias no período de acompanhamento. Conclusões: A descompressão cirúrgica nos pacientes com déficit neurológico significativo é um ponto de consenso na literatura. A ressecção subtotal seguida de radioterapia foi eficaz no tratamento dos déficits e no controle da patologia. Casos manifestos apenas por dor podem ser manejados com técnicas minimamente invasivas, seguidas ou não de radioterapia. Nível de evidência IV; Estudo terapêutico de série de casos.

Descritores: Hemangioma; Neoplasias; Coluna Vertebral.

\section{RESUMEN}

Objetivo: Presentar la serie de hemangiomas agresivos de la institución, con una revisión de las opciones de manejo descritas en la literatura. Métodos: Se trata de un levantamiento retrospectivo de los hemangiomas vertebrales agresivos atendidos por el servicio en los últimos diez años, con confirmación histológica del diagnóstico y un seguimiento mínimo de un año. Fue hecho análisis de los casos y revisión de la literatura, con énfasis en las opciones de tratamiento de esas lesiones. Resultados: Fueron encontrados siete casos, tres con dolor y cuatro con déficits neurológicos graves. Dos pacientes fueron tratados con descompresión abierta, uno con descompresión abierta y cementación, uno con descompresión abierta y artrodesis, uno con biopsia y cementación, uno con biopsia percutánea y uno con biopsia abierta seguida de cirugía descompresiva. Todos los pacientes fueron sometidos a radioterapia. Hubo regresión significativa de los déficits de presentación, pero una paciente desarrolló déficit irreversible durante el tratamiento. No hubo recidivas o complicaciones tardías en el período de acompañamiento. Conclusiones: La descompresión quirúrgica en los pacientes con déficit neurológico significativo es un punto de consenso en la literatura. La resección subtotal seguida de radioterapia fue eficaz en el tratamiento de los déficits y en el control de la patología. Los casos manifestados solo por dolor pueden ser manejados con técnicas mínimamente invasivas, seguidas o no de radioterapia. Nivel de evidencia IV; Estudio terapéutico de serie de casos.

Descriptores: Hemangioma; Neoplasias; Columna Vertebral. 


\section{INTRODUCTION}

Vertebral hemangiomas are quite common and usually behave in an extremely benign manner, without causing any kind of symptom. On rare occasions these tumors behave aggressively, causing problems ranging from pain to the development of instability and serious neurological deficits. ${ }^{1,2}$ As the number of these cases is very low, studies are based on small series and are insufficient to generate an ideal therapeutic approach or build consensus, there being a highly heterogeneous set of recommended conducts and treatment philosophies, ranging from alcoholization to en bloc resection of the tumor. This study describes a case series of hemangiomas with aggressive behavior with a brief review of the literature focused on options for managing the pathology according to its clinical presentation.

\section{METHODS}

A retrospective survey of cases of aggressive vertebral hemangiomas treated at the service over the last 10 years, with a minimum follow-up of one year and histological confirmation of the diagnosis, was conducted. Only symptomatic tumors with extraosseous extension or significant bulging of the bone were defined as aggressive vertebral hemangiomas. ${ }^{1}$ The patient signed the Informed Consent Form. Imaging studies and medical records were reviewed, with demographic, clinical presentation, treatment, complications, need for reintervention, X-ray use, and clinical improvement data being noted.

\section{RESULTS}

Seven cases were located, six of them females and one male, ranging in age from 38 to 70 years (mean of 51 years). Three patients only complained of pain in the first consultation, one who had a sacral lesion and developed serious neurological deficit (saddle anesthesia and loss of sphincter control) during treatment, following a surgical biopsy. The other four patients were diagnosed because of the appearance of neurological deficit. They had lesions of the dorsal spine with very important medullary compressions from the growth of the tumor into the spinal canal, without pathological fracture or significant instability (SINS 6 or less). ${ }^{2}$

In the three cases that presented pain, the histological diagnosis was prioritized with the intention of referral to radiotherapy. In one of them there was a lesion typical of hemangioma that occupied the entire vertebral body and caused bulging of the cortex, without presenting an exophytic component. A percutaneous biopsy and kyphoplasty were performed in the same surgical time. In another, there was a lesion suggestive of a hemangioma with exophytic soft tissue components in the canal, without significant neural compression and the option to perform only a confirmatory biopsy was chosen. In both cases, radiotherapy was performed after the biopsy results and both progressed with complete resolution of the complaints and without recurrence in one year. The third case was an insufflating sacral lesion, previously biopsied at another service with negative results for a tumor, that underwent an open sacral biopsy. Following the biopsy surgery, the patient developed saddle anesthesia and loss of sphincter control, which had not improved after 7 days of observation. A decision was made to perform decompression of the cauda equina followed by radiotherapy, but the deficits remained after treatment and the patient also developed bilateral radiculopathy in $\mathrm{S} 1$, with no evidence of tumor growth in the imaging examinations.

In the cases that presented neurological deficit, the conduct was urgent decompression surgery since all of them had severe and rapidly progressing paraparesis. Preoperative particle embolization was performed in only one patient transferred from another service, where the surgery was aborted due to bleeding during the initial phase of the laminectomy. In this case, the hemangioma remaining after decompression occupied the entire vertebral body and an open vertebroplasty was performed during the same surgical time. In the other cases, resection of the exophytic components of the tumor without prior embolization was performed, there being no major issues with bleeding. In one of these cases, posterior arthrodesis was performed, as the affected vertebra was at the apex of a kyphotic curve and there was fear that the deformity might worsen following the laminectomy. One of these patients developed paraparesis in the 30th week of pregnancy and was operated in the 36th week due to the rapid progression of the deficit. All the patients were forwarded for postoperative radiotherapy. All four patients who presented neurological deficits had important neurological improvement and returned to their habitual activities within one year following surgery. The patient who developed cauda equina syndrome after the biopsy showed no neurological improvement. There were no cases of clinical recurrence, post-treatment instability, or growth of the lesion in the imaging examinations, with a minimum follow-up of 1 year (mean of 27 months). The cases are summarized in Table 1.

\section{DISCUSSION}

Hemangiomas are extremely common vertebral tumors that behave in a very benign manner, but that, in approximately $0.9 \%$ to $1.2 \%$ of cases can cause symptoms that range from pain to serious neurological lesions. ${ }^{3-7}$

Pregnancy is a known risk factor for the development of aggressive behavior in hemangiomas. In addition to hormonal factors that can contribute to tumor growth, increased abdominal pressure causes congestion of the vertebral venous plexus, with hemodynamic repercussions in preexisting hemangiomas. This is the most common benign spinal tumor in pregnant women, especially in the 3rd trimester and in high thoracic levels. ${ }^{8}$

Hemangiomas usually appear in magnetic resonance as vertebral body lesions with a thick trabecular aspect and a hypersignal in T2. In computed tomography the appearance of a hive or polka

Table 1. Series of patients with aggressive hemangioma.

\begin{tabular}{|c|c|c|c|c|c|c|c|c|c|c|}
\hline & $\begin{array}{l}\text { Sex and } \\
\text { age }\end{array}$ & $\begin{array}{l}\text { Level of } \\
\text { the lesion }\end{array}$ & $\begin{array}{c}\text { Neural } \\
\text { compression }\end{array}$ & $\begin{array}{l}\text { Exophytic } \\
\text { component }\end{array}$ & $\begin{array}{c}\text { Neurological } \\
\text { deficit }\end{array}$ & $\begin{array}{l}\text { Surgical } \\
\text { technique }\end{array}$ & $\begin{array}{c}\text { Post- } \\
\text { Operative } \\
\text { complications }\end{array}$ & $\begin{array}{l}\text { Need for } \\
\text { reintervention }\end{array}$ & $\begin{array}{c}\text { Post-operative } \\
\text { radiotherapy }\end{array}$ & $\begin{array}{l}\text { Neurological } \\
\text { improvement }\end{array}$ \\
\hline 1 & $F-67$ & L1 & No & Yes & No & $\begin{array}{c}\text { Percutaneous } \\
\text { Biopsy } \\
\end{array}$ & No & No & Yes & Not applicable \\
\hline 2 & $M-41$ & T9 & Yes & Yes & Yes & $\begin{array}{c}\text { Open } \\
\text { decompression }\end{array}$ & No & No & Yes & Yes \\
\hline 3 & $F-40$ & T5 & No & No & No & $\begin{array}{c}\text { Biopsy + } \\
\text { kyphoplasty }\end{array}$ & No & No & Yes & Not applicable \\
\hline 4 & $F-70$ & T6 & Yes & Yes & Yes & \begin{tabular}{|c|}
$\begin{array}{c}\text { Decompression }+ \\
\text { vertebroplasty }\end{array}$ \\
\end{tabular} & No & No & Yes & Yes \\
\hline 5 & $F-61$ & $\mathrm{~T} 4$ & Yes & Yes & Yes & \begin{tabular}{|c|}
$\begin{array}{c}\text { Decompression + } \\
\text { arthrodesis }\end{array}$ \\
\end{tabular} & No & No & Yes & Yes \\
\hline 6 & $F-40$ & T3 & Yes & Yes & Yes & $\begin{array}{c}\text { Open } \\
\text { Decompression }\end{array}$ & No & No & Yes & Yes \\
\hline 7 & $F-38$ & S2-S3 & Yes & Yes & No & Open biopsy & $\begin{array}{c}\text { Saddle anesthesia } \\
\text { and loss of } \\
\text { sphincter control }\end{array}$ & $\begin{array}{c}\text { Wide } \\
\text { decompression }\end{array}$ & Yes & No \\
\hline
\end{tabular}


dots in the axial images and a striated aspect in reconstruction are typical. ${ }^{6}$ Aggressive hemangiomas tend to evolve entirely in the vertebral body, extend to the posterior elements, and present an irregular aspect with lytic areas, in addition to vertebral bulging or an exophytic soft tissue component. ${ }^{3}$

There is no consensus about the ideal form of treatment, since they are rare tumors and all the studies are made up of small series. The management options basically involve radiotherapy, alcoholization, percutaneous cementation, and resection, used alone or in different combinations.

Radiotherapy has been used since 1930 and has been proven effective in the control of pain symptoms and less severe and slowly evolving neurological deficits since the 1950s. The effect of radiotherapy on hemangiomas is dose dependent and there are several possible treatment regimens, although the most recommended dose today is $40 \mathrm{~Gy} .{ }^{9}$ Permanent improvement is reported in 77 to $100 \%$ of cases of pain and at least $60 \%$ of neurological deficits. Control of the tumor in terms of progression or recurrence is obtained in practically $100 \%$ of cases. As the response to treatment is slow, radiotherapy is not indicated as the primary treatment in cases of important neural compression or major neurological deficit. ${ }^{10}$ The radiological aspect of the vertebra in the imaging examinations does not change after radiotherapy, suggesting that radiation is effective in controlling pathological vascular tissue, but has no demonstrable effect on bone tissue, such that radiotherapy should not be used in the treatment of compressions from bulging or bone hypertrophy. ${ }^{11}$

Some authors question the use of isolated radiotherapy due to the potential for instability secondary to tumor necrosis, proposing combining its use with cementation techniques, such as vertebroplasty or kyphoplasty. ${ }^{11}$ Methacrylate injection increases vertebral body resistance, but the truth is that compressive fracture from aggressive hemangiomas are isolated cases ${ }^{12}$ within a pathology that is already quite rare. The use of cementation in lesions with epidural invasion is controversial. While some authors report reduction of the exophytic components after cementation of the vertebral body, most contraindicate the procedure, considering that the gain in resistance does not compensate for the risk of extravasation. ${ }^{13}$

Vertebroplasty has been mostly used as an alternative to radiotherapy, functioning as primary treatment for aggressive hemangiomas without neurological deficits, especially in non-exophytic lesions with massive compromise of the vertebral body. It can also be used for structural reinforcement in cases of hemangiomas treated with surgical resection.

Ablation with ethanol is another alternative to radiotherapy, with $93 \%$ good results in a series of 14 patients, including those with neurological déficits, ${ }^{14}$ but some authors mention a greater risk of vertebral collapse from necrosis and advocate the concomitant use of cementation. Because its efficacy is equivalent to that of other treatments and there are reports of significant complications, such as osteonecrosis, neurological deterioration, or medullary lesion, alcoholization has been relegated to the second level in most protocols. ${ }^{4}$

Several authors report good results using direct or endovascular embolization as a standalone treatment, ${ }^{15,16}$ even in cases with significant neurological deficit, but there are also series that failed to demonstrate improvement with this procedure. Embolization is more often used as a preoperative measure in resection surgeries, with the benefit of a statistically confirmed reduction in transoperative bleeding. ${ }^{17}$ It does involve risks and it is contraindicated when tumor afferents are in close proximity to the Adamkiewicz artery. ${ }^{18}$

Surgical decompression is accepted as a standard treatment for lesions causing neural compression, but the degree of resection necessary and the need for prior embolization are still open for discussion. ${ }^{19}$

Complete tumor exeresis is noted for low recurrence without the need for radiotherapy, ${ }^{20}$ while partial resection without postoperative radiotherapy has a recurrence of 30 to $50 \%$. On the other hand, complete resection implies more aggressive surgeries, greater bleeding, the need for instrumentation, and greater morbidity, for the treatment of a histologically benign lesion that has an extremely low rate recurrence after radiotherapy. ${ }^{21}$

Some authors, such as Ogawa et al.,22 advocate preoperative embolization followed by en bloc resection in order to prevent recurrence, however, in their series of 5 cases, the mean surgical time was 10 hours with bleeding of $2400 \mathrm{ml}$ and a complication rate close to $36 \%$.

Most authors agree with the use of minimally invasive techniques, such as alcoholization, cementation, or radiotherapy in lesions that do not cause deficit, and subtotal resection followed by radiotherapy in lesions with neurological deficit or neural compression. Although surgery for a post-radiation relapse may be more complex, ${ }^{21}$ the degree of tumor recurrence is extremely low and radical surgery is considered quite aggressive as the primary treatment for a non-malignant tumor.

Based on their experience with 16 cases, Cloran et al., ${ }^{23}$ proposed a treatment algorithm, considering mainly the clinical condition of the patient, in which less invasive procedures are used in cases without neurological deficit and in patients not in good condition for surgery, with surgical resection being used in cases of neurological deficit. (Figure 1)

Several management options centered on the clinical presentation were used in our cases. In the patients with significant neurological deficit, surgical decompression is a point of consensus among the authors. Subtotal resection seems to us to be the most logical and safe surgical option. Radiotherapy was performed after histological confirmation in all cases, since its high effectiveness in terms of tumor control and recurrence prevention is another point of consensus. ${ }^{22}$ Although several articles mention the risk of necrosis, fracture, or instability following radiotherapy, none of the series presents cases where this actually occurred and, although we had performed cementations to strengthen the vertebra in some cases, it is possible that radiotherapy alone would have been sufficient to treat these patients. Pathological fracture seems to be quite rare among aggressive hemangiomas and the clearest indications for stabilization are postoperative iatrogenic instability and tumors with SINS above six points. ${ }^{2}$

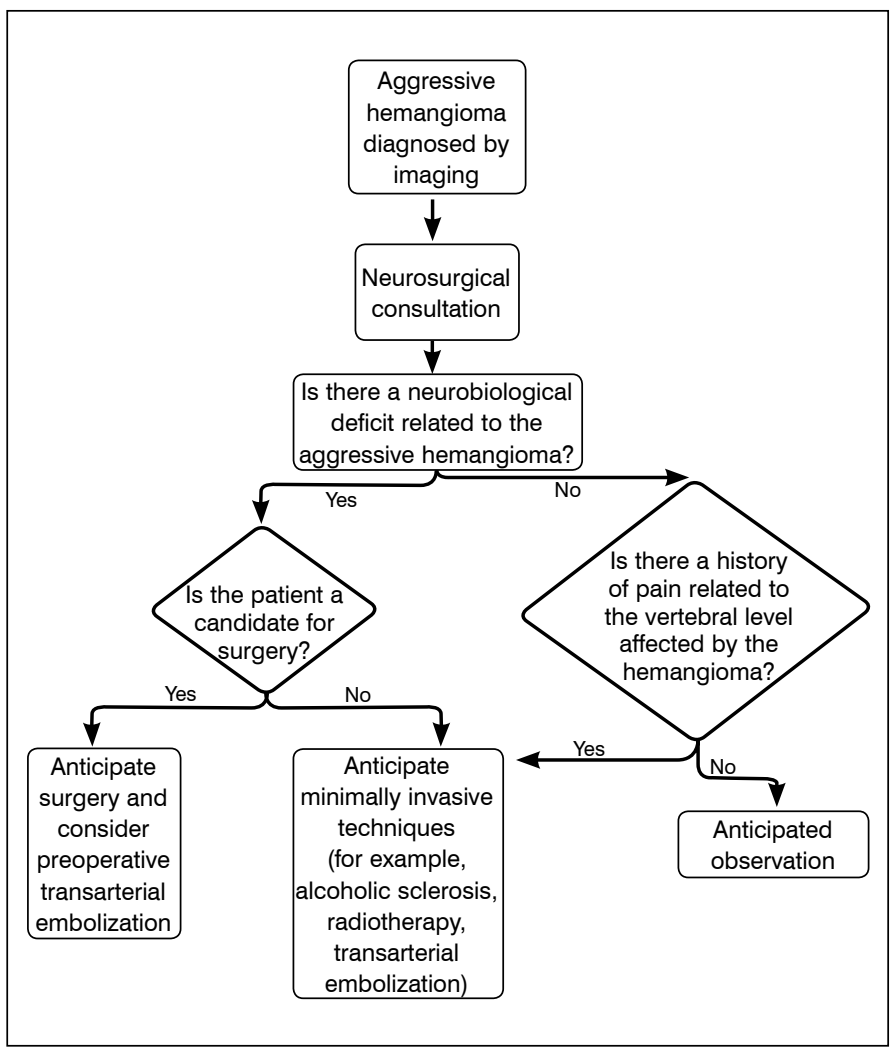

Figure 1. Treatment algorithm considering the clinical condition (Cloran et al..$^{23}$ ) 
The techniques of embolization or alcoholization did not seem interesting to us as a primary treatment because they present neurological risk and are not more effective than radiotherapy in terms of tumor control.

\section{CONCLUSIONS}

Our idea is that radiotherapy should be the basis of treatment for aggressive hemangioma, preceded by decompression surgery in cases of significant canal invasion or neurological deficit, with stabilization procedures when necessary.

All authors declare no potential conflict of interest related to this article.

CONTRIBUTION OF THE AUTHORS: Each author made significant individual contributions to this manuscript. MSS: writing, review, and performing the surgeries; LXL, EVA: surgeries, data analysis, and writing; BAO: statistical analysis, surgeries, and review; GJM: statistical analysis and review.

\section{REFERENCES}

1. Pastushyn Al, Slin'ko El, Mirzoyeva GM. Vertebral hemangiomas: diagnosis, management, natural history and clinicopathological correlates in 86 patients. Surg Neurol. 1998;50(6):535-47.

2. Steinmetz MP, Benzel EC. Benzel's spine surgery: techniques, comlication avoidance, and management, Fourth edition. Amsterdam: Elsevier; 2017.

3. Vasudeva VS, Chi JH, Groff MW. Surgical treatment of aggressive vertebral hemangiomas. Neurosurg Focus. 2016;41(2): E7.

4. Eisenstein S, Spiro F, Browde S, Allen CM, Grobler L. The treatment of a symptomatic vertebral hemangioma by radiotherapy. A case report. Spine (Phila Pa 1976). 1986:11(6):640-2

5. Faria SL, Schlupp WR, Chiminazzo H Jr. Radiotherapy in the treatment of vertebral hemangiomas. Int J Radiat Oncol Biol Phys. 1985;11(2):387-90.

6. Friedman DP. Symptomatic vertebral hemangiomas: MR findings. AJR Am J Roentgenol. 1996;167(2):359-64

7. Mohan V, Gupta SK, Tuli SM, Sanyal B. Symptomatic vertebral haemangiomas. Clin Radiol. 1980;31(5):575-9.

8. Kiroglu Y, Benek B, Yagci B, Cirak B, Tahta K. Spinal cord compression caused by vertebral hemangioma being symptomatic during pregnancy. Surg Neurol. 2009;71(4):487-92.

9. Rades D, Bajrovic A, Alberti W, Rudat V. Is there a dose-effect relationship for the treatment of symptomatic vertebral hemangioma? Int J Radiat Oncol Biol Phys. 2003:55(1):178-81.

10. Glanzmann C, Rust M, Horst W. Radiotherapie bei Angiomen der Wirbelsaule, Ergebnisse bei 62 Patienten aus dem Zeitraum 1939-1975. Strahlentherapy. 1977;153:522-5.

11. Sedeño BP, Ibarria NR, Hamdai HM, Varela TF, Arregui ISM, Verde DM, et al. First reported treatment of aggressive hemangioma with intraoperative radiation therapy and kyphoplasty (Kypho-IORT). Clin Transl Radiat Oncol. 2017;2:19-22.

12. Tarantino $R$, Donnarumma $P$, Nigro $L$, Delfini R. Surgery in extensive vertebral hemangioma: case report, literature review and a new algorithm proposal. Neurosurg Rev. $2015 ; 38(3): 585-92$

13. Evangelopoulos DS, Kontovazenitis P, Kokkinis K, Glynos M, Korres DS, Sapkas G. Cement leakage in a symptomatic vertebral hemangioma: a case report and review of the literature. Cases J. 2009:2:7148.

14. Doppman JL, Oldfield EH, Heiss JD. Symptomatic vertebral hemangiomas: treatment by means of direct intralesional injection of ethanol. Radiology. 2000;214(2):341-8

15. Gross $\mathrm{CE}$, Hodge $\mathrm{CH}$ Jr, Binet EF, Kricheff II. Relief of spinal block during embolization of a vertebral body hemangioma. Case report. J Neurosurg. 1976;45(3):327-30.

16. Raco A, Ciappetta P, Artico M, Salvati M, Guidetti G, Guglielmi G. Vertebral hemangiomas with cord compression: the role of embolization in five cases. Surg Neurol. 1990;34(3):164-8

17. Robinson Y, Sheta R, Salci K, Willander J. Blood loss in surgery for aggressive vertebral haemangioma with and withoutembolisation. Asian Spine J. 2015;9(3):483-91.

18. Djindjian M, Nguyen JP, Gaston A, Pavlovitch JM, Poirier J, Awad IA. Multiple vertebral hemangiomas with neurological signs. Case report. J Neurosurg. 1992;76(6):1025-8.

19. Cloran FJ, Pukenas BA, Loevner LA, Aquino C, Schuster J, Mohan S. Aggressive spinal haemangiomas: imaging correlates to clinical presentation with analysis of treatment algorithm and clinical outcomes. Br J Radiol. 2015;88(1055):20140771.

20. Acosta FL Jr, Dowd CF, Chin C, Tihan T, Ames CP, Weinstein PR. Current treatment strategies and outcomes in the management of symptomatic vertebral hemangiomas. Neurosurgery. 2006;58(2):287-95.

21. Kato S, Kawahara N, Murakami H, Demura S, Yoshioka K, Okayama T, et al. Surgical management of aggressive vertebral hemangiomas causing spinal cord compression: long-term clinical follow-up of five cases. J Orthop Sci. 2010;15(3):350-6.

22. Ogawa R, Hikata T, Mikami S, Fujita N, Iwanami A, Watanabe $K$, et al. Total en bloc spondylectomy for locally aggressive vertebral hemangioma causing neurological déficits. Case Rep Orthop. 2015;2015:72436.

23. Cloran FJ, Pukenas BA, Loevner LA, Aquino C, Schuster J, Mohan S. Aggressive spinal haemangiomas: imaging correlates to clinical presentation with analysis of treatment algorithm and clinical outcomes. Br J Radiol. 2015;88(1055):20140771. 